Published in final edited form as:

J Nat Prod. 2016 November 23; 79(11): 2883-2889. doi:10.1021/acs.jnatprod.6b00645.

\title{
Acetophenone Monomers from Acronychia trifoliolata
}

Katsunori Miyake $^{\dagger}$, Airi Suzuki ${ }^{\dagger}$, Chihiro Morita ${ }^{\dagger}$, Masuo Goto ${ }^{\ddagger}$, David J. Newman $§$, Barry R. O’Keefe $^{\perp}$, Susan L. Morris-Natschke ${ }^{\ddagger}$, Kuo-Hsiung Lee ${ }^{\ddagger}, \|$, and Kyoko Nakagawa-Goto ${ }^{\dagger, \ddagger},{ }^{*}$

†School of Pharmaceutical Sciences, College of Medical, Pharmaceutical and Health Sciences, Kanazawa University, Kanazawa, 920-1192, Japan

¥Natural Products Research Laboratories, UNC Eshelman School of Pharmacy, University of North Carolina at Chapel Hill, Chapel Hill, North Carolina 27599-7568, United States

$\S$ NIH Special Volunteer, Wayne, Pennsylvania 19087, United States

${ }^{\perp}$ Natural Products Branch, Developmental Therapeutics Program, Division of Cancer Treatment and Diagnosis, National Cancer Institute, NCl at Frederick, Frederick, Maryland 21702-1201, United States

"Chinese Medicine Research and Development Center, China Medical University and Hospital, 2 Yuh-Der Road, Taichung, 40447, Taiwan

\section{Abstract}

Seven new [acronyculatins I-O (1-7)] and four known acetophenone monomers were isolated from a $\mathrm{CH}_{3} \mathrm{OH} / \mathrm{CH}_{2} \mathrm{Cl}_{2}$ (1:1) extract (N089419) of Acronychia trifoliolata provided by the U.S. National Cancer Institute (NCI, Frederick, MD, USA). Their structures were characterized by using various NMR and HRMS techniques. Among the known compounds, the structure of acronyculatin B (8) was revised. Some of the isolated compounds were evaluated for antiproliferative activity against human cancer cell lines. While most of the tested compounds were not cytotoxic, acronyculatins I (1) and J (2) showed moderate antiproliferative activity.

\section{Graphical Abstract}

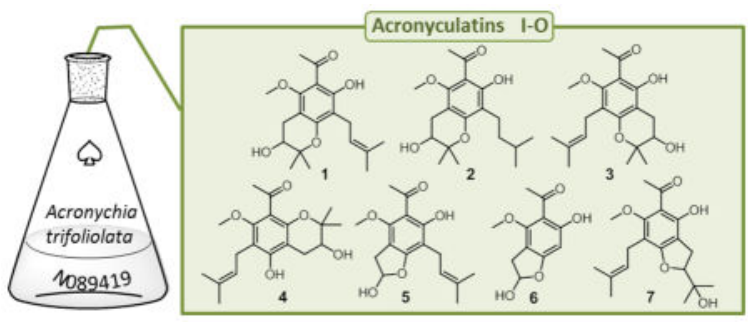

*Corresponding Author: Phone (K. Nakagawa-Goto): +81-76-264-6305. kngoto@p.kanazawa-u.ac.jp.

The authors declare no competing financial interest.

Supporting Information

The Supporting Information is available free of charge on the ACS Publications website at DOI: 10.1021/acs.jnat-prod.6b00645.

NCI-60 human tumor cell line assay data for the crude organic extract of $A$. trifoliolata, ${ }^{1} \mathrm{H}$ NMR/H-H COSY/ NOESY spectra and HRMS for $\mathbf{1 - 8},{ }^{13} \mathrm{C}$ NMR/HMQC/HMBC spectra for $\mathbf{1}, \mathbf{5}$, and $\mathbf{7}$, optical rotations for $\mathbf{1 - 4 , 7}$, and $\mathbf{8}$, as well as ${ }^{1} \mathrm{H}$ NMR $/{ }^{13} \mathrm{C}$ NMR data for $\mathbf{7}$ and $\mathbf{8}(\mathrm{PDF})$ 
The genus Acronychia (Rutaceae) contains about 48 species $^{1}$ of small trees or shrubs found in tropical regions of China, Southeast Asia, India, Australia, and islands of the Pacific Ocean. Many species have been used in traditional folk medicines for the treatment of diarrhea, cough, asthma, sores, ulcers, itchy skin, scales, pain, and rheumatism. ${ }^{2,3}$ Phytochemical and pharmacological studies on almost half of these species have revealed the presence of flavonoids, cinnamic acids, lignans, coumarins, steroids, and triterpenoids as secondary metabolites. ${ }^{2}$ The most distinctive metabolites of Acronychia are prenylated acetophenones $^{3-10}$ and furoquinoline alkaloids. ${ }^{10-12}$

Acronychia trifoliolata Zoll. \& Moritzi is distributed from Java and Christmas Island to the Solomon Islands and is locally called "batjaena alae" in Sulawesi, Indonesia, and "kaya djerouk" in Australia. ${ }^{2}$ A literature search showed a single report on this species. It described the isolation of three acetophenone dimers as well as their cytotoxic activities. ${ }^{7}$ In the course of studies focused on the discovery of bioactive natural products with new structures from rainforest plants, $A$. trifoliolata was selected for further investigation. A $\mathrm{CH}_{3} \mathrm{OH} / \mathrm{CH}_{2} \mathrm{Cl}_{2}$ (1:1) extract of $A$. trifoliolata (N089419), provided by the U.S. National Cancer Institute (NCI, Frederick, MD, USA), exhibited potent antiproliferative activity against several human tumor cell lines. Because the NCI had no more material available, the project was started using the limited amount ( $4.9 \mathrm{~g}$ ) of extract. Herein the isolation and structure elucidation of 12 secondary metabolites, including seven new acetophenone monomers, are described.

\section{RESULTS AND DISCUSSION}

Analysis of the crude organic extract of $A$. trifoliolata in the NCI-60 human tumor cell assay indicated that the extract was broadly cytotoxic, inhibiting the growth of $50 \%$ of tested cancer cells at a mean concentration of $0.3 \mu \mathrm{g} / \mathrm{mL}$ and killing those cells at a mean concentration of $1.7 \mu \mathrm{g} / \mathrm{mL}$ (Figure S1, Supporting Information). On the basis of this initial activity, the extract was selected for identification of its bioactive chemical constituents.

The $50 \% \mathrm{CH}_{3} \mathrm{OH} / \mathrm{CH}_{2} \mathrm{Cl}_{2}$ extract of the bark of A. trifoliolata $(4.9 \mathrm{~g}$ ) was fractionated with EtOAc and water to provide EtOAc- and water-soluble fractions. The EtOAc-soluble fraction was separated by a combination of MPLC, silica gel column chromatography, and preparative thin-layer chromatography (TLC) techniques to give seven new acetophenone monomers, acronyculatins I-O (1-7), together with the known acronycu-latin B (8), ${ }^{3}$ acronyculatin E (9) ${ }^{3}$ acronyculatin G (10), ${ }^{5}$ 1- $\left[2^{\prime}, 4^{\prime}\right.$-dihydroxy- $6^{\prime}$-methoxy- $3^{\prime}, 5^{\prime}$-di $\left(3^{\prime \prime}\right.$ methyl-2" -butenyl)]-phenylethanone (11), ${ }^{13}$ and acronylin $(\mathbf{1 2})^{14}$ as shown in Figure 1.

Compound 1 showed a protonated molecular ion at $\mathrm{m} / z 335.1845$ in the HRFABMS, corresponding to the molecular formula $\mathrm{C}_{19} \mathrm{H}_{26} \mathrm{O}_{5}$. The IR absorption bands at 3442, 2978, and $1616 \mathrm{~cm}^{-1}$ indicated hydroxy, hydrogen-bonded hydroxy, and carbonyl groups, respectively. The ${ }^{1} \mathrm{H}$ NMR data of $\mathbf{1}$ (Table 1 ) showed signals assignable to an olefinic $\left(\delta_{\mathrm{H}}\right.$ $5.22)$, an oxymethine $\left(\delta_{\mathrm{H}} 3.83\right)$, two methylenes $\left[\delta_{\mathrm{H}} 3.29(2 \mathrm{H}, \mathrm{d}, J=7.2 \mathrm{~Hz}), 2.97(1 \mathrm{H}, \mathrm{dd}, J\right.$ $=16.8,5.2 \mathrm{~Hz})$, and $2.72(1 \mathrm{H}, \mathrm{dd}, J=16.8,6.4 \mathrm{~Hz})]$, a methoxy $\left(\delta_{\mathrm{H}} 3.75\right)$, an acetyl $\left(\delta_{\mathrm{H}}\right.$ 2.68 ), four methyls $\left(\delta_{\mathrm{H}} 1.79,1.67,1.374\right.$, and 1.365$)$, and a hydrogen-bonded hydroxy proton $\left(\delta_{\mathrm{H}} 13.25\right)$. The ${ }^{13} \mathrm{C}$ NMR data of $\mathbf{1}$ (Table 1$)$ revealed 19 signals, including those of 
a ketocarbonyl $\left(\delta_{\mathrm{C}} 203.3\right)$, a pair of olefinic carbons $\left(\delta_{\mathrm{C}} 131.4\right.$ and 122.2$)$, six aromatic carbons $\left(\delta_{\mathrm{C}} 161.1,159.7,157.4,113.2,109.3\right.$, and 104.3$)$, an oxygenated tertiary carbon $\left(\delta_{\mathrm{C}}\right.$ $77.8)$, and an oxymethine $\left(\delta_{\mathrm{C}} 69.2\right)$. These data resembled those of the known acronyculatin $\mathrm{G}(\mathbf{1 0}),{ }^{5}$ which was also isolated in this study, except for the C-1" ${ }^{\prime \prime}$ benzylic methylene and C-2" oxymethine in 1 instead of an olefinic moiety in 10. The 2D NMR experiments, including $\mathrm{H}-\mathrm{H}$ COSY, HMQC, and HMBC, revealed the presence of a benzene moiety fully substituted with an acetyl, a hydroxy, a prenyl, a methoxy, and a 2,3-dioxygenated 2methylbutane moiety (Figure 2). The latter moiety was likely a 2,2-dimethyl-3,4dihydro- $2 H$-pyran ring system, as suggested by the molecular formula of $\mathbf{1}$. On the basis of several observations, the dihydropyran ring was fused to the benzene at C- $4^{\prime}$ and $\mathrm{C}-5^{\prime}$, while the prenyl group was attached at C- $3^{\prime}$. These assignments, as well as those of the acetyl, hydroxy, and methoxy groups, were supported by the NOE correlations observed between the $\mathrm{C}-1^{\prime \prime}$ dihydropyran methylene protons and the C- $6^{\prime}$ methoxy protons and between the $\mathrm{C}-1^{\prime \prime \prime}$ methylene protons and the $\mathrm{C}-2^{\prime}$ hydroxy proton. Second, the phenolic proton showed intramolecular hydrogen bonding with the carbonyl oxygen of the acetyl group. Thus, the structure of $\mathbf{1}$ was concluded to be 1-[3,7-dihydroxy-5-methoxy-2,2dimethyl-8-(3-methylbut-2-en-1-yl)chroman-6-yl]ethan-1-one, a hydrated derivative of 10. ${ }^{5}$ It was given the trivial name acronyculatin I following the related acetophenone monomers acronyculatins A-H ${ }^{3,5}$ from Acronychia species.

The ${ }^{1} \mathrm{H}$ NMR spectrum of $\mathbf{2}$ was similar to that of $\mathbf{1}$. However, the olefinic signal in $\mathbf{1}$ was absent, while aliphatic signals were observed at $\delta_{\mathrm{H}} 1.55(2 \mathrm{H}, \mathrm{m})$ and $1.35(1 \mathrm{H}, \mathrm{m})$. The protonated molecular ion peak of 2 was observed at $\mathrm{m} / z 337.2012$, indicative of two additional hydrogens in the structure of $\mathbf{2}$ versus $\mathbf{1}$. On the basis of these data, compound $\mathbf{2}$ contains a hydrogenated prenyl group compared with $\mathbf{1}$ and was fully characterized as 1 (3,7-dihydroxy-8-isopentyl-5-methoxy-2,2-dimethylchroman-6-yl)-ethan-1-one and named acronyculatin $\mathrm{J}$.

Compound 3 showed a protonated molecular ion at $m / z 335.1850$ in the HRFABMS, corresponding to the same molecular formula, $\mathrm{C}_{19} \mathrm{H}_{26} \mathrm{O}_{5}$, as $\mathbf{1}$. The ${ }^{1} \mathrm{H}$ NMR data (Table 1) of 3 were closely comparable to those of the known acronyculatin $\mathrm{E}(\mathbf{9}){ }^{3}$ which was coisolated in this study, except for benzylic methylene $\left(\delta_{\mathrm{H}} 2.90,2.69\right)$ and oxymethine $\left(\delta_{\mathrm{H}}\right.$ 3.84 ) signals in $\mathbf{3}$ compared with two olefinic proton peaks in $\mathbf{9}$. Collectively, these observations implied the presence of a dihydropyran in $\mathbf{3}$ rather than the pyran in $\mathbf{9}$. A hydrogen-bonded phenolic proton $\left(\delta_{\mathrm{H}} 13.60\right)$ suggested that this ring was attached at C-3' and $\mathrm{C}-4^{\prime}$ of the benzene moiety. The NOESY correlations observed between the prenyl benzylic methylene protons at $\mathrm{C}-1^{\prime \prime \prime}\left(\delta_{\mathrm{H}} 3.26\right)$ and the methoxy protons $\left(\delta_{\mathrm{H}} 3.72\right)$ established that the prenyl group in 3 was attached to $\mathrm{C}-5^{\prime}$ on the benzene moiety. Thus, compound 3, acronyculatin $\mathrm{K}$, was characterized as 1-[3,5-dihydroxy-7-methoxy-2,2dimethyl-8-(3-methylbut-2-en-1-yl)chroman-6-yl]ethan-1-one.

The ${ }^{1} \mathrm{H}$ NMR data of 4 (Table 1) resembled those of $\mathbf{3}$, except for the presence of a nonhydrogen-bonded phenolic proton $\left(\delta_{\mathrm{H}} 5.74\right)$ in 4 instead of a hydrogen-bonded proton $\left(\delta_{\mathrm{H}}\right.$ $13.60)$ in 3. On the basis of the NOESY correlations of the prenyl benzylic methylene signals at $\delta_{\mathrm{H}} 3.35(2 \mathrm{H}$, brd, $J=7.2 \mathrm{~Hz})$ with those of methoxy and phenolic protons at $\delta_{\mathrm{H}}$ $3.71(3 \mathrm{H}, \mathrm{s})$ and $\delta_{\mathrm{H}} 5.74(1 \mathrm{H}, \mathrm{s})$, respectively, the prenyl group in 4 was located at $\mathrm{C}-5^{\prime}$ of 
the chromane moiety. In addition, HRFABMS data of compound $\mathbf{4}$ showed the molecular formula $\mathrm{C}_{19} \mathrm{H}_{26} \mathrm{O}_{5}$, which suggested the presence of a dihydropyran ring in the structure. As the phenolic proton $\left(\delta_{\mathrm{H}} 5.74\right)$ did not show any hydrogen bonding, the dihydropyran ring was linked at the benzene $\mathrm{C}-2^{\prime}$ and $\mathrm{C}-3^{\prime}$ positions. Compound 4 , acronyculatin $\mathrm{L}$, was, therefore, identified as 1-[3,5-dihydroxy-7-methoxy-2,2-dimethyl-6-(3-methylbut-2-en-1yl)chroman-8-yl]ethan-1-one. Compounds 3 and $\mathbf{4}$ are regioisomers, differing in the positions of the dihydropyran and phenolic group, i.e., $\mathrm{C}^{\prime} / \mathrm{C}^{\prime}{ }^{\prime}$ and $\mathrm{C}-2^{\prime}$ versus $\mathrm{C} 2^{\prime} / \mathrm{C} 3^{\prime}$ C- $4^{\prime}$, respectively.

The ${ }^{1} \mathrm{H}$ NMR data of 5 (Table 1) revealed the presence of an acetyl group $\left(\delta_{\mathrm{H}} 2.62,3 \mathrm{H}, \mathrm{s}\right)$, a hydrogen-bonded phenolic proton $\left(\delta_{\mathrm{H}} 14.00,1 \mathrm{H}, \mathrm{s}\right)$, a methoxy moiety $\left(\delta_{\mathrm{H}} 3.91,3 \mathrm{H}, \mathrm{s}\right)$, and a prenyl group (olefinic proton at $\delta_{\mathrm{H}} 5.24,1 \mathrm{H}$, brt, $J=6.6 \mathrm{~Hz}$; methylene at $\delta_{\mathrm{H}} 3.26,2 \mathrm{H}, \mathrm{d}, J$ $=6.6 \mathrm{~Hz}$; gem-dimethyls at $\delta_{\mathrm{H}} 1.76$ and 1.67 , each $3 \mathrm{H}$, brs, respectively), which were similar to those of 1 . However, signals for a methylene $\left(\delta_{\mathrm{H}} 3.46,1 \mathrm{H}, \mathrm{dd}, J=16.2,6.0 \mathrm{~Hz}\right.$, and $\left.\delta_{\mathrm{H}} 3.16,1 \mathrm{H}, \mathrm{dd}, J=16.2,2.4 \mathrm{~Hz}\right)$, a hydroxy $\left(\delta_{\mathrm{H}} 3.18,1 \mathrm{H}, \mathrm{d}, J=4.8 \mathrm{~Hz}\right)$, and hemiacetal $\left(\delta_{\mathrm{H}} 6.14,1 \mathrm{H}\right.$, ddd, $\left.J=6.4,4.8,2.4 \mathrm{~Hz}\right)$ protons were observed for 5 instead of those for a dihydropyran moiety in $\mathbf{1}$. The HMBC cross-peaks of the methylene and hemiacetal protons with $\mathrm{C}-4^{\prime}\left(\delta_{\mathrm{C}} 162.9\right)$ supported the presence of a dihydrofuran ring. On the basis of the NOESY spectrum that showed a correlation between the hydrogen-bonded phenolic proton and the prenyl methylene group, the prenyl group was located at C-3'. Accordingly, the structure of $\mathbf{5}$, acronyculatin $\mathrm{M}$, was concluded to be 1-[2,6-dihydroxy-4methoxy-7-(3-methylbut-2-en-1-yl)-2,3-dihydro-benzofuran-5-yl]ethan-1-one.

According to HRFABMS analysis, the molecular weight of 6 is $\mathrm{C}_{11} \mathrm{H}_{12} \mathrm{O}_{5}$, which implied the loss of a five-carbon unit from 5 . This assumption was confirmed by the ${ }^{1} \mathrm{H}$ NMR spectrum of $\mathbf{6}$, in which the proton signals related to a prenyl group were clearly absent, while an aromatic proton $\left(\delta_{\mathrm{H}} 6.17,1 \mathrm{H}, \mathrm{s}\right)$ was present. A NOESY correlation between the methoxy protons $\left(\delta_{\mathrm{H}} 3.96,3 \mathrm{H}, \mathrm{s}\right)$ and benzylic methylene $\left(\delta_{\mathrm{H}} 3.17,1 \mathrm{H}, \mathrm{dd}, J=15.6,2.4 \mathrm{~Hz}\right.$ and $3.46,1 \mathrm{H}$, dd, $J=15.6,6.0 \mathrm{~Hz}$ ) on the dihydrofuran moiety suggested that $\mathbf{6}$, acronyculatin $\mathrm{N}$, is a deprenylated derivative of $\mathbf{5}$.

Compounds 1-6 displayed small specific rotation values as shown in the Supporting Information. Compound 1 was esterified using Mosher's reagent in an attempt to define the $\mathrm{C}-2^{\prime \prime}$ absolute configuration. Although the specific rotation of $\mathbf{1}$ was slightly negative $\left([a]^{21} \mathrm{D}-2.7, c 0.1, \mathrm{CH}_{3} \mathrm{OH}\right)$, the resulting Mosher esters existed as a 1:1 mixture of diastereomers based on the ${ }^{1} \mathrm{H}$ NMR observation, as shown in Figure 3. Therefore, the specific resolution value could be considered within the range of error. The extremely small isolated quantities of the remaining new compounds were insuficient for further investigation. However, it is highly possible that compounds $\mathbf{2 - 6}$ could also be racemates, because their biosynthesis pathways would presumably proceed similarly.

Compound 7 showed a protonated molecular ion at $\mathrm{m} / z 335.1845$ in the HRFABMS, corresponding to the molecular formula $\mathrm{C}_{19} \mathrm{H}_{26} \mathrm{O}_{5}$. The ${ }^{1} \mathrm{H}$ and ${ }^{13} \mathrm{C}$ NMR spectra of 7 were closely similar to those of known acronyculatin B $(\mathbf{8}),{ }^{3}$ also isolated in this study. They differed only in the spin patterns of the benzylic methylene on the dihydrofuran ring $\left(\delta_{\mathrm{H}}\right.$ 3.14 and 3.04 for $7 ; \delta_{\mathrm{H}} 3.26$ for 8$)$ and the hydrogen-bonded hydroxy proton $\left(\delta_{\mathrm{H}} 13.30\right.$ for 
7; $\delta_{\mathrm{H}} 14.52$ for 8 ). The 2D NMR experiments revealed that the benzene moiety of 7 was fully substituted with acetyl, hydroxy, methoxy, prenyl, and dihydrofuran groups. A NOESY experiment revealed correlations between the methoxy protons and the acetyl methyl protons at $\delta_{\mathrm{H}} 2.67(3 \mathrm{H}, \mathrm{s})$ as well as the prenyl benzylic methylene protons at $\delta_{\mathrm{H}} 3.25(2 \mathrm{H}, \mathrm{brd}, J=$ $6.4 \mathrm{~Hz}$ ). On the basis of these data, the structure of 7 would be assigned as identical to that of $\mathbf{8}$, which was reported previously. ${ }^{3}$ However, in $\mathrm{CDCl}_{3}$, the two benzylic (prenyl and dihydrofuran) signals of $\mathbf{8}\left(\delta_{\mathrm{H}} 3.26\right.$ and 3.22) were overlapped and could not be distinguished. In contrast, in acetone- $d_{6}$ (Supporting Information), the corresponding signals were resolved. Furthermore, from a NOESY experiment, the dihydrofuran benzylic methylene protons $\left(\delta_{\mathrm{H}} 3.36\right)$ were correlated with the methoxy protons $\left(\delta_{\mathrm{H}} 4.00\right)$. These new data indicated that the hydroxy and the methoxy groups in the reported structure of acronyculatin B (8) should be reversed. ${ }^{15}$ It should be noted that acronyculatin B isolated from $A$. trifoliolata was a racemate, while an optically active compound was isolated from A. pedunculata. ${ }^{3}$

The antiproliferative activity of selected acetophenone monomers, $\mathbf{1 - 4 , 7}$, and $\mathbf{8}$, was evaluated. Acetophenones $\mathbf{1}$ and $\mathbf{2}$ exhibited $\mathrm{IC}_{50}$ values around $20 \mu \mathrm{M}$, while the four remaining acetophenones showed $\mathrm{IC}_{50}$ values in excess of $40 \mu \mathrm{M}$ against several human tumor cell lines, as shown in Table 2. These results indicated that a pyran moiety is favored relative to a furan ring for antiproliferative activity ( 1 vs 8$)$. The location of substituents could also affect the activity. For example, a hydroxy group positioned to participate in hydrogen bonding to a neighboring carbonyl group was important for activity (1 vs $\mathbf{4}$ ).

Eleven acetophenone monomers, including seven new compounds were isolated from the rainforest plant $A$. trifoliolata Zoll. \& Moritzi. Their chemical structures were characterized from NMR, HRMS, and IR spectroscopic data. Information regarding the total syntheses and additional biological evaluation of the compounds will be reported elsewhere. ${ }^{16}$

\section{EXPERIMENTAL SECTION}

\section{General Experimental Procedures}

Optical rotations were recorded on a JASCO P-2200 digital polarimeter. Infrared spectra (IR) were measured with a Shimadzu FTIR-8700 instrument for samples in $\mathrm{CHCl}_{3}$. NMR spectra were recorded on JEOL JMN-ECA600 and JMN-ECS400 spectrometers with tetramethylsilane as an internal standard, and chemical shifts are expressed as $\delta$ values. HRMS data were obtained on a JMS-SX102A (FAB) or JMS-T100TD (DART) mass spectrometer. Analytical and preparative TLC were carried out on precoated silica gel $60 \mathrm{~F}_{254}$ and $\mathrm{RP}-18 \mathrm{~F}_{254}$ plates $(0.25$ or $0.50 \mathrm{~mm}$ thickness; Merck). MPLC was performed with silica gel and C18 cartridges (Biotage, Uppsala Sweden).

\section{Plant Material}

The bark of $A$. trifoliolata was collected in Bali, Indonesia, at an altitude of $1200 \mathrm{~m}$ on July 5, 1994, by Dr. Djaja D. Soejarto and identified by taxonomist A. McDonald. A voucher specimen (\#U44Z-4773) is housed at the Smithsonian Institution, Washington, DC, and a 
voucher extract (N089419) was deposited at the NCI and Kanazawa University (Kanazawa, Japan).

\section{NCl-60 Cell Cytotoxicity Assay}

Analysis of the cytotoxicity of the crude organic extract of $A$. trifoliolata was achieved by testing in vitro a 60-cell tumor screening panel of the $\mathrm{NCI}$ as reported previously. ${ }^{17}$ Briefly, a single $100 \mu \mathrm{g} / \mathrm{mL}$ concentration of organic extract $\mathrm{N} 089419$ was tested against 60 human cancer cell lines. Upon initial indication of activity in the single-dose experiment, the extract was subsequently tested at five doses starting at $100 \mu \mathrm{g} / \mathrm{mL}$ and decreasing by logarithmic dilution to a final concentration of $0.01 \mu \mathrm{g} / \mathrm{mL}$. Cell viability after $48 \mathrm{~h}$ of incubation was visualized using sulforhodamine B as reported previously. ${ }^{17}$

\section{Extraction and Isolation}

A $\mathrm{CH}_{3} \mathrm{OH} / \mathrm{CH}_{2} \mathrm{Cl}_{2}$ (1:1) extract of the bark of $A$. trifoliolata $\left(4.9 \mathrm{~g}\right.$ ) was dissolved in $\mathrm{H}_{2} \mathrm{O}$ and partitioned with EtOAc to yield EtOAc-soluble ( $3.8 \mathrm{~g}$ ) and $\mathrm{H}_{2} \mathrm{O}$-soluble fractions. The $\mathrm{H}_{2} \mathrm{O}$-soluble fraction was subjected to Diaion HP-20 column chromatography with $\mathrm{CH}_{3} \mathrm{OH} / \mathrm{H}_{2} \mathrm{O}(0,30,50,70$, and $100 \%)$ to yield five fractions. The EtOAc-soluble fraction $(3.7 \mathrm{~g})$ was dissolved into EtOAc, the precipitate was removed, and the EtOAc-soluble portion was subjected to silica gel MPLC (KP-Sil $100 \mathrm{~g}$ ) with a $\mathrm{CH}_{3} \mathrm{OH} / \mathrm{CHCl}_{3}$ gradient system [0:1 (5 fractions) $\rightarrow$ 2:98 (5 fractions) $\rightarrow$ 10:90 (5 fractions) $\rightarrow$ 1:0 (1 fraction); collection per $100 \mathrm{~mL}$ ] to yield 16 fractions.

Fraction $2(750 \mathrm{mg}$ ) was subjected to silica gel MPLC (SNAP HP-Sil $25 \mathrm{~g}$ ) with EtOAc/nhexane [1:19, 12 column volumes (CVs) and 1:4, $5 \mathrm{CVs}$ ] followed by $\mathrm{CH}_{3} \mathrm{OH}$ to yield 18 subfractions. Subfraction $4(50.6 \mathrm{mg})$ was purified by preparative TLC with toluene/ $n$ hexane (1:1), reversed-phase MPLC (KP-C18-HS $12 \mathrm{~g}$ ) with $60 \%$ acetone $/ \mathrm{H}_{2} \mathrm{O}$, and preparative TLC with EtOAc/toluene (1:9) to yield acronyculatin O (7, 1.4 mg), 1-[2', $4^{\prime}$ dihydroxy-6' -methoxy-3', $5^{\prime}$-di(3"'-methyl-2" -butenyl)]phenylethanone (11, $\left.9.5 \mathrm{mg}\right)$, and acronyculatins $\mathrm{E}(\mathbf{9}, 0.8 \mathrm{mg}), \mathrm{L}(\mathbf{4}, 0.5 \mathrm{mg})$, and $\mathrm{G}(\mathbf{1 0}, 0.4 \mathrm{mg})$.

Fraction $3\left(150 \mathrm{mg}\right.$ ) was subjected to silica gel MPLC (SNAP Ultra $10 \mathrm{~g}$ ) with $\mathrm{CHCl}_{3}(15$ $\mathrm{CVs}$ ) followed by $\mathrm{CH}_{3} \mathrm{OH}$ to yield 16 subfractions. Subfraction $3(63.7 \mathrm{mg})$ was purified by MPLC on silica gel (SNAP Ultra $10 \mathrm{~g}$ ) with EtOAc/ $n$-hexane (1:19, $15 \mathrm{CVs}$ ) and EtOAc, followed by reversed-phase preparative TLC with $\mathrm{CH}_{3} \mathrm{OH} / \mathrm{H}_{2} \mathrm{O} / \mathrm{HOAc}$ (90:9:1), to afford acronyculatins $\mathrm{K}(\mathbf{3}, 0.6 \mathrm{mg})$ and $\mathrm{B}(\mathbf{8}, 0.6 \mathrm{mg})$.

Fraction 4 (155 mg) was subjected to MPLC on silica gel (Zip Sphere $5 \mathrm{~g}$ ) with a $\mathrm{CH}_{3} \mathrm{OH} / \mathrm{CH}_{2} \mathrm{Cl}_{2}$ gradient system [0:1 (6 fractions) $\rightarrow$ 1:99 (4 fractions) $\rightarrow$ 2:98 (3 fractions) $\rightarrow$ 5:95 (2 fractions); collection per $10 \mathrm{~mL}$ ] to yield 15 subfractions. Subfraction $7(2.4 \mathrm{mg})$ was combined with subfraction 3 of fraction $5(16.3 \mathrm{mg})$, then purified by normal-phase preparative TLC with EtOAc/n-hexane (3:7) and EtOAc/toluene (1:4) or reversed-phase preparative TLC with $\mathrm{CH}_{3} \mathrm{CN} / \mathrm{H}_{2} \mathrm{O}$ (4:1), to afford acronyculatins $\mathrm{M}(\mathbf{5}, 0.8$ $\mathrm{mg})$ and $\mathrm{N}(\mathbf{6}, 0.3 \mathrm{mg})$ and acronylin $(\mathbf{1 2}, 0.6 \mathrm{mg})$.

Fraction $5(290 \mathrm{mg}$ ) was subjected to MPLC on silica gel (Zip Sphere $10 \mathrm{~g}$ ) with a $\mathrm{CH}_{3} \mathrm{OH} / \mathrm{CH}_{2} \mathrm{Cl}_{2}$ gradient system $[0: 1(6 \mathrm{CVs}) \rightarrow 1: 99(6 \mathrm{CVs}) \rightarrow 2: 98(6 \mathrm{CVs}) \rightarrow 10: 90$ 
$(1 \mathrm{CV})]$ to yield 19 subfractions. Subfraction $4(153 \mathrm{mg})$ was further purified by reversedphase MPLC (KP-C18-HS 12 g) with $\mathrm{CH}_{3} \mathrm{OH} / \mathrm{H}_{2} \mathrm{O}$ (9:1, $6 \mathrm{CVs}$ ), then $\mathrm{CH}_{3} \mathrm{OH}(5 \mathrm{CVs})$, followed by reversed-phase preparative TLC with $\mathrm{CH}_{3} \mathrm{CN} / \mathrm{H}_{2} \mathrm{O} / \mathrm{HOAc}$ (80:19:1) and normal-phase preparative TLC with acetone/toluene (9:1) and EtOAc/ $n$-hexane (2:3), to yield acronyculatins $\mathrm{I}(\mathbf{1}, 1.2 \mathrm{mg})$ and $\mathrm{J}(\mathbf{2}, 0.3 \mathrm{mg})$.

Acronyculatin I(I): colorless, amorphous solid; IR $v_{\max }\left(\mathrm{CHCl}_{3}\right) \mathrm{cm}^{-1} 3442,2978,2928$, 1616, 1592, 1444, 1366, $1291 ;{ }^{1} \mathrm{H}$ and ${ }^{13} \mathrm{C}$ NMR, Table 1; FABMS $\mathrm{m} / z$ 335, 279;

HRFABMS $\mathrm{m} / z 335.1845[\mathrm{M}+\mathrm{H}]^{+}\left(\right.$calcd for $\left.\mathrm{C}_{19} \mathrm{H}_{27} \mathrm{O}_{5}, 335.1858\right)$.

Acronyculatin J(2): colorless, amorphous solid; IR $v_{\max }\left(\mathrm{CHCl}_{3}\right) \mathrm{cm}^{-1} 3443,2952,2953$, 1615, 1433, 1365, 1279; ${ }^{1} \mathrm{H}$ NMR, Table 1; FABMS $\mathrm{m} / z$ 337; HRFABMS $m / z 337.2012$ [M $+\mathrm{H}]^{+}\left(\right.$calcd for $\left.\mathrm{C}_{19} \mathrm{H}_{29} \mathrm{O}_{5}, 337.2015\right)$.

Acronyculatin $K(3)$ : colorless, amorphous solid; IR $v_{\max }\left(\mathrm{CHCl}_{3}\right) \mathrm{cm}^{-1} 3443,2923,1613$, 1415, 1366, 1268; ${ }^{1} \mathrm{H}$ NMR, Table 1; FABMS $m / z$ 335; HRFABMS $m / z 335.1850[\mathrm{M}+\mathrm{H}]^{+}$ (calcd for $\mathrm{C}_{19} \mathrm{H}_{27} \mathrm{O}_{5}, 335.1858$ ).

Acronyculatin L (4): colorless, amorphous solid; IR $v_{\max }\left(\mathrm{CHCl}_{3}\right) \mathrm{cm}^{-1} 3435,2925,1686$, 1595, 1421, 1367; ${ }^{1} \mathrm{H}$ NMR, Table 1; FABMS m/ $z$ 335, 279; HRFABMS $\mathrm{m} / z 335.1828$ [M $+\mathrm{H}]^{+}$(calcd for $\mathrm{C}_{19} \mathrm{H}_{27} \mathrm{O}_{5}, 335.1858$ ).

Acronyculatin $M(5)$ : colorless, amorphous solid; IR $v_{\max }\left(\mathrm{CHCl}_{3}\right) \mathrm{cm}^{-1} 3353,2923,1614$, 1416, 1370; ${ }^{1} \mathrm{H}$ and ${ }^{13} \mathrm{C}$ NMR, Table 1; FABMS $m / z$ 293, 237, HRFABMS $m / z 293.1392$ $[\mathrm{M}+\mathrm{H}]^{+}$(calcd for $\left.\mathrm{C}_{16} \mathrm{H}_{21} \mathrm{O}_{5}, 293.1389\right)$.

Acronyculatin N(6): colorless, amorphous solid; IR $v_{\max }\left(\mathrm{CHCl}_{3}\right) \mathrm{cm}^{-1} 3445,2918,2359$, 1620, 1421, 1366; ${ }^{1} \mathrm{H}$ NMR, Table 1; FABMS $\mathrm{m} / \mathrm{z} 225$; HRFABMS $\mathrm{m} / \mathrm{z} 225.0764[\mathrm{M}+\mathrm{H}]^{+}$ (calcd for $\mathrm{C}_{11} \mathrm{H}_{13} \mathrm{O}_{5}, 225.0764$ ).

Acronyculatin $O$ (7): colorless, amorphous solid; IR $v_{\max }\left(\mathrm{CHCl}_{3}\right) \mathrm{cm}^{-1} 3453,2929,1614$, 1423, 1366; ${ }^{1} \mathrm{H}$ and ${ }^{13} \mathrm{C}$ NMR, Table 1; FABMS $\mathrm{m} / z$ 335; HRFABMS $\mathrm{m} / z 335.1845[\mathrm{M}+$ $\mathrm{H}]^{+}$(calcd for $\mathrm{C}_{19} \mathrm{H}_{27} \mathrm{O}_{5}, 335.1858$ ).

Acronyculatin $B(8)$ : colorless, amorphous solid; IR $v_{\max }\left(\mathrm{CHCl}_{3}\right) \mathrm{cm}^{-1} 3434,2919,1615$, 1367; FABMS $\mathrm{m} / \mathrm{z} 335$; HRFABMS $\mathrm{m} / \mathrm{z} 335.1814[\mathrm{M}+\mathrm{H}]^{+}$(calcd for $\mathrm{C}_{19} \mathrm{H}_{27} \mathrm{O}_{5}$, $335.1858)$.

\section{Esterification of Compound 1 with (S)-MTPACI}

To a solution of $1(0.6 \mathrm{mg}, 0.002 \mathrm{mmol})$ in anhydrous $\mathrm{CH}_{2} \mathrm{Cl}_{2}(0.2 \mathrm{~mL})$ were added $\mathrm{Et}_{3} \mathrm{~N}$ (1.0 $\mu \mathrm{L}, 0.007 \mathrm{mmol})$, 4-dimethylaminopyridine (DMAP) (0.6 mg, $0.005 \mathrm{mmol}$ ), and ( $S$ )$\operatorname{MTPACl}(1.0 \mu \mathrm{L}, 0.005 \mathrm{mmol})$ at rt. After stirring for $21 \mathrm{~h}, \mathrm{Et}_{3} \mathrm{~N}(2.0 \mu \mathrm{L}, 0.014 \mathrm{mmol})$, DMAP (1.3 mg, $0.01 \mathrm{mmol})$, and $(S)$-MTPACl $(2.0 \mu \mathrm{L}, 0.01 \mathrm{mmol})$ were added to the mixture, and stirring continued for $6 \mathrm{~h}$. The mixture was purified using preparative TLC with EtOAc/n-hexane (1:2) to afford the MTPA ester $(0.6 \mathrm{mg}, 61 \%)$ as a $1: 1$ diastereomeric mixture. 
Mosher ester of 1: ${ }^{1} \mathrm{H}$ NMR (400 MHz, $\left.\mathrm{CDCl}_{3}\right) \delta 13.2$ and $13.2(1 \mathrm{H}, \mathrm{s}, 7-\mathrm{O} H, 1: 1), 5.19-$ $5.14\left[1 \mathrm{H}, \mathrm{m}, 8-\mathrm{CH}_{2} \mathrm{CH}=\mathrm{C}\left(\mathrm{CH}_{3}\right)_{2}\right], 5.19-5.14(1 \mathrm{H}, \mathrm{m}, 3-\mathrm{H}), 3.65$ and $3.64\left(3 \mathrm{H}, \mathrm{s}, 5-\mathrm{OCH}_{3}\right.$, $1: 1), 3.27$ and $3.25\left[2 \mathrm{H}, \mathrm{d}, J=4.8 \mathrm{~Hz}, 8-\mathrm{CH}_{2} \mathrm{CH}=\mathrm{C}\left(\mathrm{CH}_{3}\right)_{2}, 1: 1\right], 3.07$ and $3.05(1 \mathrm{H}, \mathrm{dd}, J=$ $6.8,3.2 \mathrm{~Hz}, 4-H, 1: 1), 2.92$ and $2.76(1 \mathrm{H}, \mathrm{dd}, J=11.2,3.6 \mathrm{~Hz}, 4-H, 1: 1), 2.67$ and $2.66(3 \mathrm{H}$, s, 6-Ac, 1:1), 1.76 and $1.73\left[3 \mathrm{H}, \mathrm{s}, 8-\mathrm{CH}_{2} \mathrm{CH}=\mathrm{C}\left(\mathrm{CH}_{3}\right)_{2}, 1: 1\right], 1.65$ and $1.61[3 \mathrm{H}, \mathrm{s}, 8-$ $\left.\mathrm{CH}_{2} \mathrm{CH}=\mathrm{C}\left(\mathrm{CH}_{3}\right)_{2}, 1: 1\right], 1.36$ and 1.33 [3H, s, 2- $\left.\left(\mathrm{CH}_{3}\right)_{2}, 1: 1\right], 1.32$ and $1.30[3 \mathrm{H}, \mathrm{s}, 2-$ $\left.\left(\mathrm{CH}_{3}\right)_{2}, 1: 1\right]$.

\section{Supplementary Material}

Refer to Web version on PubMed Central for supplementary material.

\section{Acknowledgments}

This study was supported by a Grant-in-Aid from the Ministry of Education, Culture, Sports, Science and Technology (MEXT KAKENHI, Japan), awarded to K.N.G. (Grant Number 25293024). This work was also supported by NIH Grant CA177584 from the National Cancer Institute, awarded to K.H.L. We also thank the Biological Testing Branch, DTP, DCTD, NCI, for performing the NCI 60-cell cytotoxicity assay and the Natural Products Support Group, Leidos Biomedical Inc., for plant extraction.

\section{References}

1. Hartley, TG.; Wilson, A., editors. Flora of Australia: Meliaceae, Rutaceae, Zygophyllaceae. Vol. 26ABRS. Canberra \& CSIRO; Melbourne: 2013. p. 104-118.

2. Epifano F, Fiorito S, Genovese S. Phytochemistry. 2013; 95:12-18. [PubMed: 23920228]

3. Su CR, Kuo PC, Wang ML, Liou MJ, Damu AG, Wu TS. J Nat Prod. 2003; 66:990-993. [PubMed: 12880321]

4. Yang X, Zhang YB, Wu ZN, Zhang XQ, Jiang JW, Li YL, Wang GC. Fitoterapia. 2015; 105:156159. [PubMed: 26160157]

5. Kozaki S, Takenaka Y, Mizushina Y, Yamaura T, Tanahashi T. J Nat Med. 2014; 68:421-426. [PubMed: 24129772]

6. Kouloura E, Halabalaki M, Lallemand MC, Nam S, Jove R, Litaudon M, Awang K, Hadi HA, Skaltsounis AL. J Nat Prod. 2012; 75:1270-1276. [PubMed: 22708987]

7. Oyama M, Bastow KF, Tachibana Y, Shirataki Y, Yamaguchi S, Cragg GM, Wu TS, Lee KH. Chinese Pharm J. 2003; 55:239-245.

8. Sy LK, Brown GD. Phytochemistry. 1999; 52:681-683.

9. De Silva LB, Herath WM, Lyanage C, Kumar V, Ahmad VU, Sultana A. Phytochemistry. 1991; 30:1709-1710.

10. Kumar V, Karunaratne V, Meegalle MRSK. Phytochemistry. 1989; 28:1278-1279.

11. De Silva LB, De Silva ULL, Mahendran M, Jennings R. Phytochemistry. 1979; 18:1255-1256.

12. Lahey FN, McCamish M. Tetrahedron Lett. 1968; 12:1525-1527. [PubMed: 5640105]

13. Kumar V, Karunaratne V, Sanath MR, Meeegalle K. Phytochemistry. 1989; 28:1278-1279.

14. Jain AC, Zutshi MK. Tetrahedron Lett. 1971; 34:3179-3182.

15. The structure of acronyculatin B in Su's paper (ref 3) is different from their assignment in the text, which clearly indicated the proposed structure in this study.

16. Morita C, Kobayashi Y, Tokuda H, Saito Y, Miyake K, Suzuki N, Ichiishi E, Lee KH, NakagawaGoto K. J Nat Prod. Submitted.

17. Boyd MR, Paull KD. Drug Dev Res. 1995; 34:91-109. 

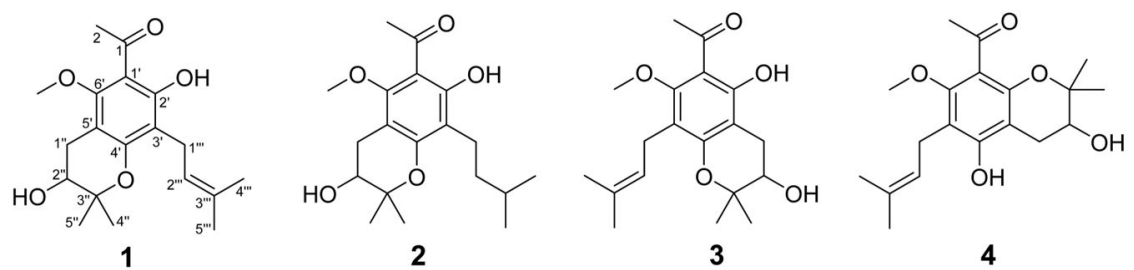

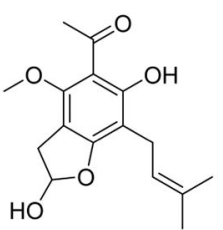

5

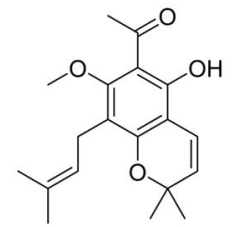

Acronyculatin E (9)

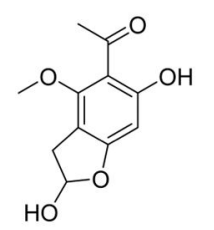

6

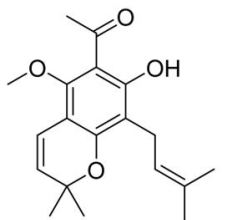

Acronyculatin G (10)

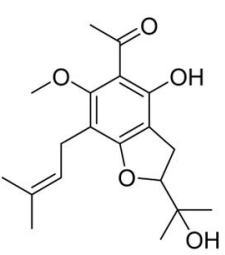

7

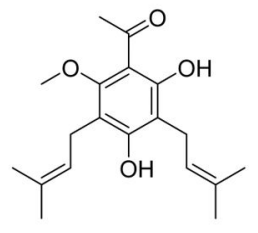

11
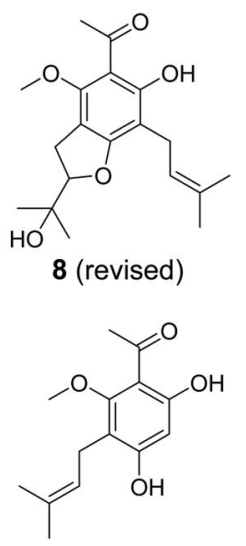

Acronylin (12)

Figure 1.

Structures of compounds 1-12 isolated from A. trifoliolata. 

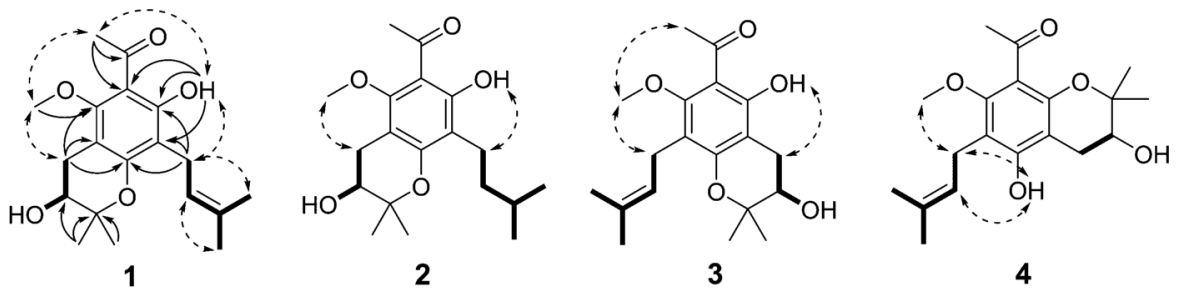

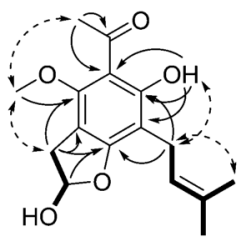

5

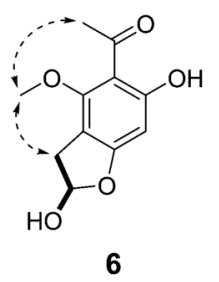

6
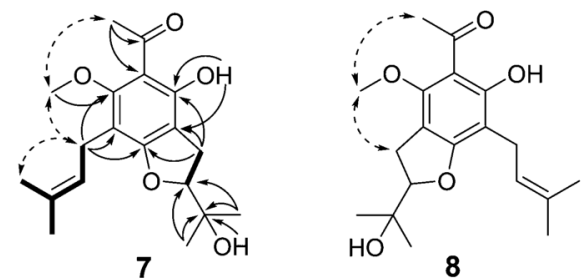

Figure 2.

Selected HMBC correlations (arrows), COSY connectivities (bold lines), and NOESY correlations (dotted arrows) for 1-8. 
<smiles>COc1c2c(c(CC=C(C)C)c(O)c1C(C)=O)OC(C)(C)C(O)C2</smiles><smiles>CCO[14C](=[W])OC1Cc2c(c(CC=C(C)C)c(O)c(C(C)=O)c2OC)OC1(C)C</smiles>

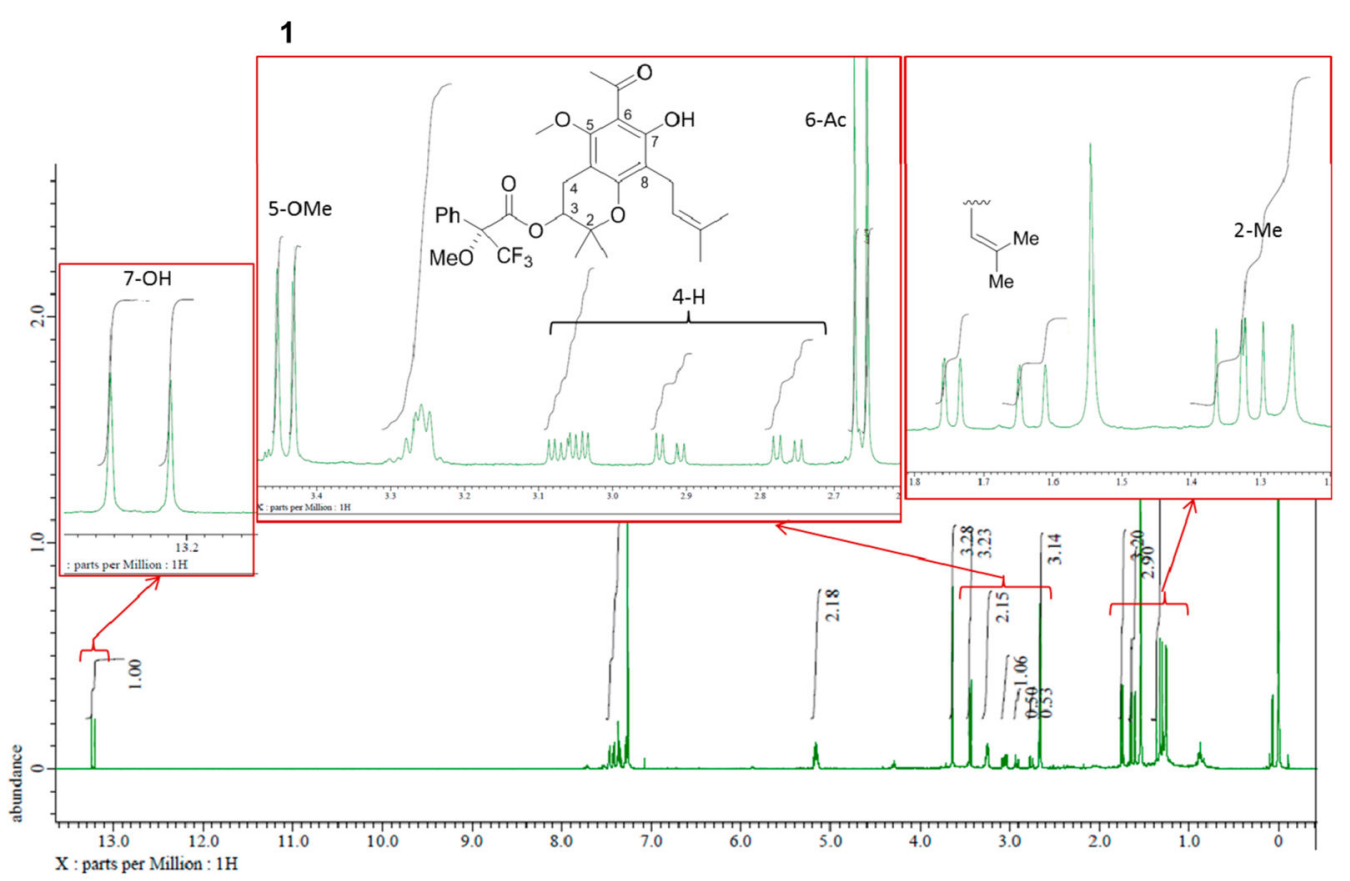

Figure 3.

MTPA ester of 1 and ${ }^{1} \mathrm{H}$ NMR spectrum. 


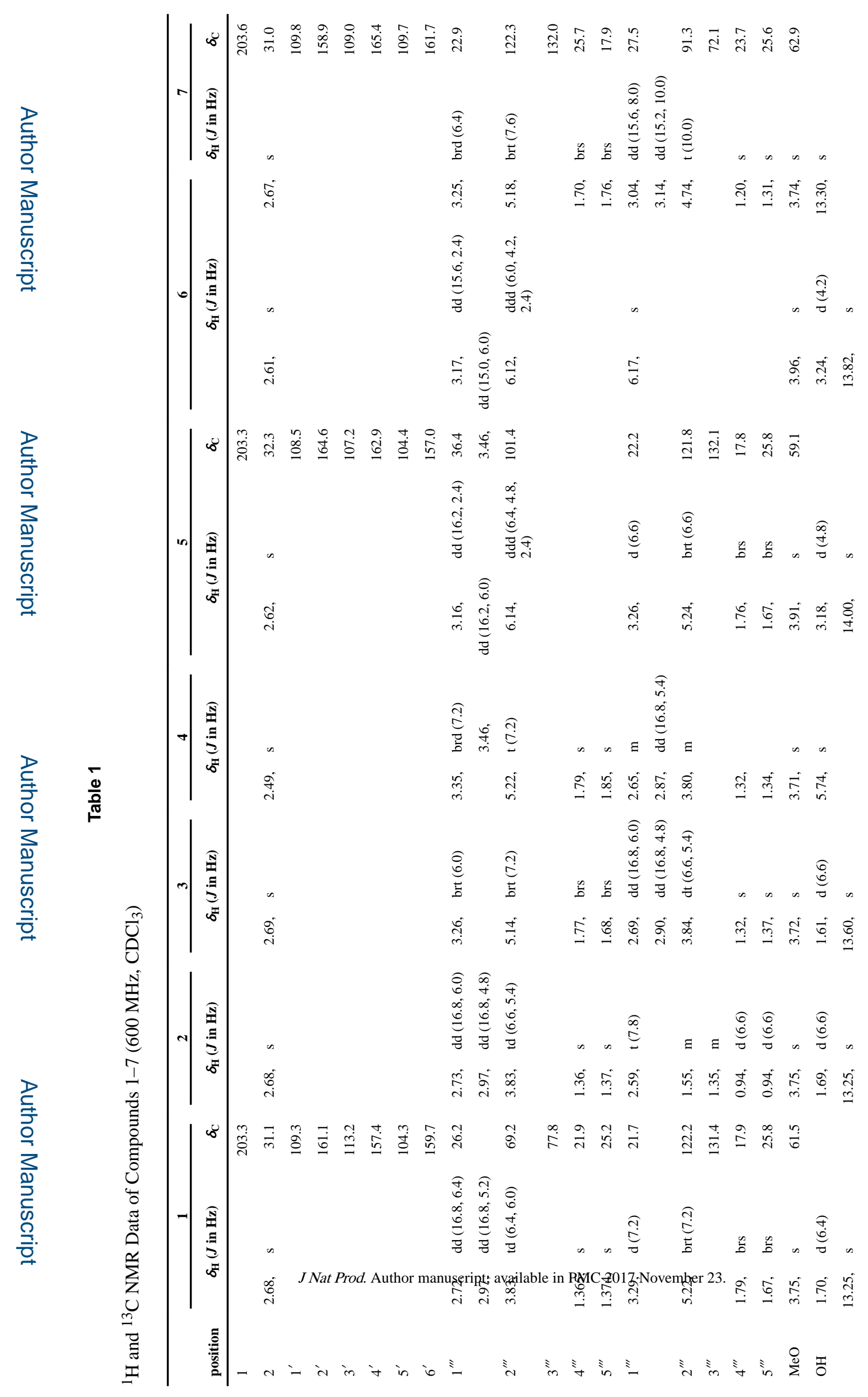



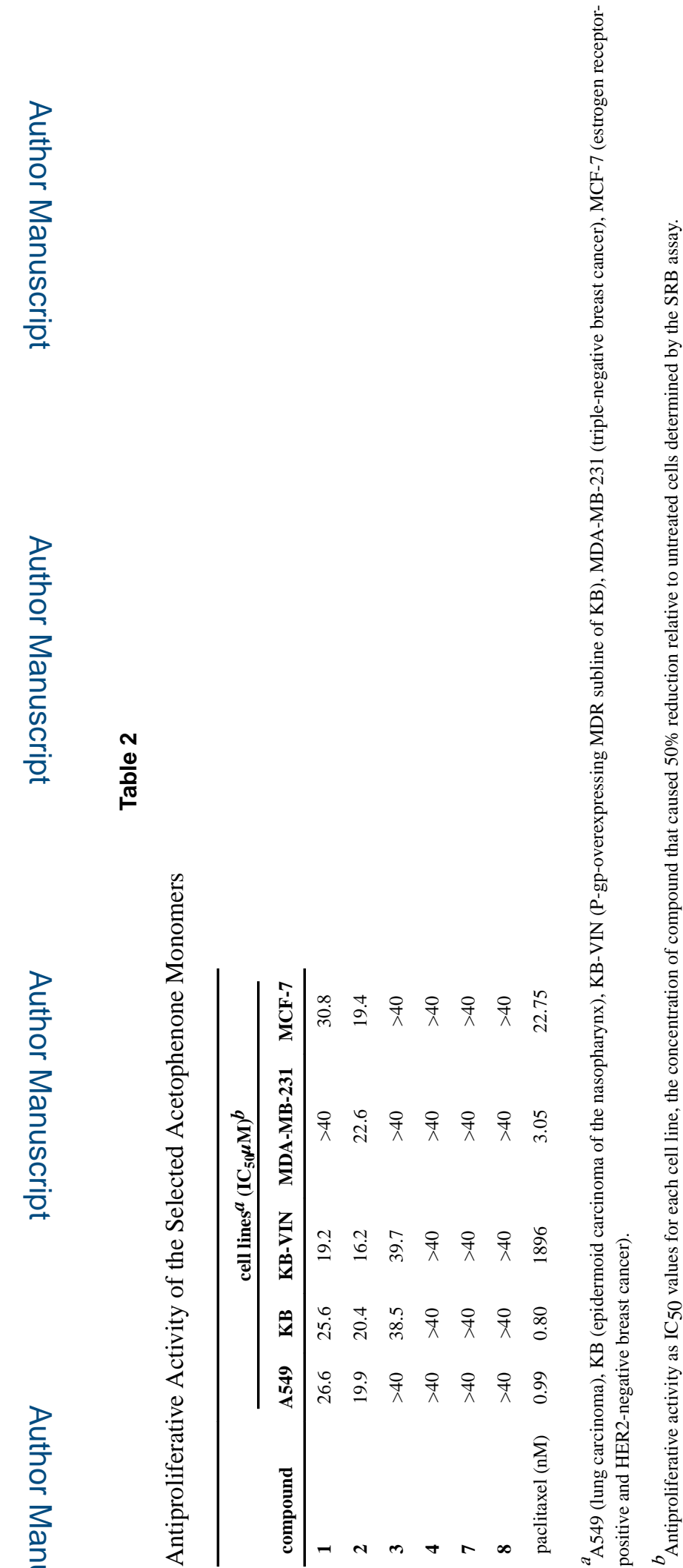

J Nat Prod. Author manuscript; available in PMC 2017 November 23. 